\title{
Predation on a Blindsnake Genus Typhlops (Squamata: Typhlopidae) by the Spanish Flag Anole, Anolis allogus (Squamata: Dactyloidae) in Cuba
}

Tomás M. Rodríguez-Cabrera ${ }^{1}$ and Ansel Fong G. ${ }^{2}$

${ }^{1}$ Jardín Botánico de Cienfuegos, Pepito Tey, Cienfuegos, CP 59290, Cuba (tomasmichel.rodriguez@gmail.com)

${ }^{2}$ Centro Oriental de Ecosistemas y Biodiversidad (BIOECO), Museo de Historia Natural “Tomás Romay,” Santiago de Cuba, CP 90100 , Cuba (ansel@bioeco.cu)

Photographs by the senior author.

$\mathrm{T}$ he Blindsnake family Typhlopidae (Squamata: Scolecophidia) comprises well over 40 currently recognized native West Indian species in as many as four genera (Hedges et al. 2014; but see also Pyron and Wallach 2014 and Nagy et al. 2015), plus the introduced invasive and parthenogenetic Braminy Blindsnake (Indotyphlops braminus; e.g., Wallach 2009; Hedges et al. 2014; Pyron and Wallach 2014; Domínguez 2015). In Cuba, 12 native species of Blindsnakes are currently recognized, four in the genus Typhlops and eight in the genus Cubatyphlops, in addition to I. braminus (Domínguez et al. 2013; Díaz and Cádiz 2014; Hedges et al. 2014; Pyron and Wallach 2014; Domínguez 2015). However, both in Cuba and throughout the region, additional species remain to be described (Hedges et al. 2014).

Probably attributable primarily to their secretive habits, the natural history of Blindsnakes is poorly known (e.g., Vitt and Caldwell 2009). In the West Indies, predators have been reported for only five species (see review in Henderson and Powell 2009; Table 1), representing only about $11 \%$ of all West Indian Blindsnakes. Moreover, these reports are limited to eight predators, most of them snakes in the family Dipsadidae (Henderson and Powell 2009; Table 1). The only known instance of a lizard preying on a Blindsnake was a male Puerto Rican Crested Anole (Anolis cristatellus) eating a Puerto Rican Coastal Blindsnake (Antillotyphlops hypomethes, referred therein to the genus Typhlops, Colón 2009). Herein we report the second instance of a West Indian anole preying on a Blindsnake, in this case from eastern Cuba.

At $0838 \mathrm{~h}$ on 9 June 2015, we observed an adult male Spanish Flag Anole (Anolis allogus Barbour and Ramsden 1919; 59 mm SVL, $3.8 \mathrm{~g}$ ) eating a Blindsnake (Typhlops sp.; $155 \mathrm{~mm} \mathrm{SVL}$ ) midway up the ascending path to El Yunque $\left(20^{\circ} 20^{\prime} 41.9^{\prime \prime} \mathrm{N},-74^{\circ} 34^{\prime} 01.5^{\prime \prime} \mathrm{W}\right.$, WGS 84; $394 \mathrm{~m}$ asl),
Baracoa, Guantánamo Province, Cuba. The lizard was resting on a bush trunk ( $8.5 \mathrm{~mm}$ diameter, $110 \mathrm{~cm}$ above the ground) in an almost vertical position with $57 \mathrm{~mm}$ (37\% of SVL) of

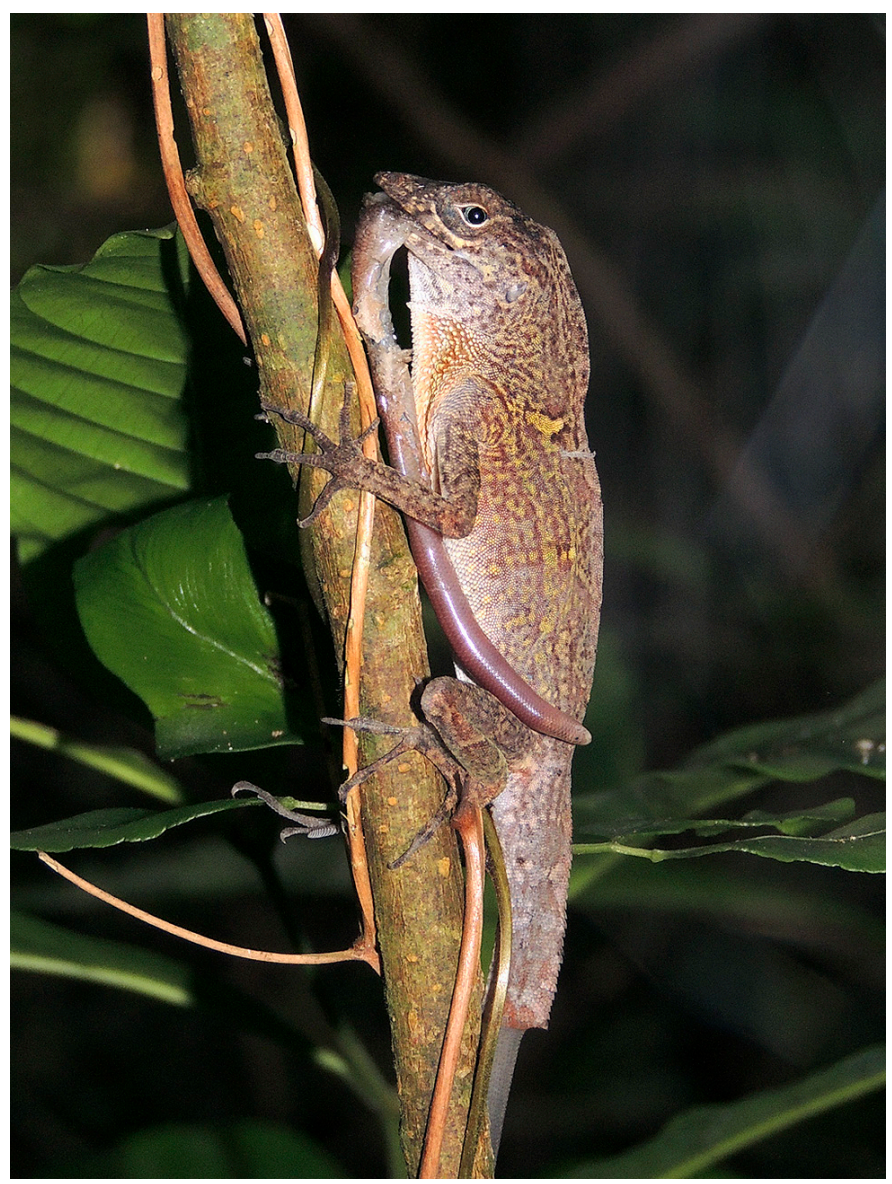

Fig. 1. Male Spanish Flag Anole (Anolis allogus) consuming a Blindsnake (Typhlops sp.) along the ascending path to El Yunque, Baracoa, Guantánamo Province. 
Table 1. Predators reported for Blindsnakes (Typhlopidae) in the West Indies. Note that Pyron and Wallach (2014) did not recognize Antillotyphlops and Cubatyphlops, which they considered junior synonyms of Typhlops (see, however, Nagy et al. 2015). Consequently, snakes from Cuba (except for the report in this paper), Jamaica, and Puerto Rico, listed below as "Typhlops sp.," might be in the genera Cubatyphlops or Antillotyphlops.
Predator
Prey
Island
Source

Amphibia: Anura

Leptodactylidae

Leptodactylus fallax

Antillotyphlops dominicanus

Dominica

Brooks (1982)

\section{Reptilia: Squamata}

Dactyloidae

\begin{tabular}{llll}
\hline Anolis cristatellus & Antillotyphlops hypomethes & Puerto Rico & Colón (2009) \\
\hline Anolis allogus & Typhlops sp. & Cuba & This paper \\
\hline
\end{tabular}

Dipsadidae

\begin{tabular}{llll}
\hline Arrhyton taeniatum & Typhlops sp. & Cuba & Schwartz and Henderson (1991) \\
\hline Borikenophis portoricensis & Antillotyphlops platycephalus & Puerto Rico & Henderson and Sajdak (1996) \\
\hline & Typhlops sp. & Puerto Rico & Schwartz and Henderson (1991) \\
\hline Ialtris agyrtes & Typhlops pusillus & Hispaniola & Schwartz and Rossman (1976) \\
\hline Magliophis stahli & Typhlops sp. (adults and eggs) & Puerto Rico & Rivero (1998) \\
\hline Schwartzophis funereum & Typhlops sp. (eggs) & Jamaica & Schwartz and Henderson (1991) \\
\hline
\end{tabular}

\section{Aves: Ciconiiformes}

Ardeidae

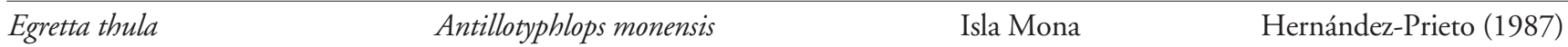

the Blindsnake's anterior body hanging from its mouth (Fig. 1). The snake was gently removed. Only about $25 \mathrm{~mm}$ of the snake's anterior body remained intact, the rest was substantially damaged (Fig. 2B) apparently due to mastication. Both the snake and lizard are deposited in the herpetological collection of BIOECO, Santiago de Cuba (Field number: AFG-3205).

Anolis allogus (Fig. 3) is a Cuban endemic trunk-ground ecomorph widely distributed throughout the archipelago and locally common. It is most frequently associated with shaded forests (Henderson and Powell 2009; Rodríguez Schettino et al. 2013). It feeds mostly on arthropods, including insects (cockroaches, beetles, flies, hemipterans, ants, termites, lepidopteran larvae, orthopterans, barklice), crustaceans, millipedes, and spiders (see review in Henderson and Powell 2009), but it also consumes smaller vertebrates, including other anoles such as grass-bush ecomorphs (Socarrás et al. 1988).

Blindsnakes are burrowers and rarely venture onto the surface, but some have been observed in arboreal situations presumably searching for prey (e.g., Henderson and Powell 2009; Vitt and Caldwell 2009). The instance of predation reported herein suggests that the Blindsnake was on the surface by day, during the diurnal activity period of Anolis allogus. The predominant vegetation at the observation site (i.e., rainforest on limestone) produces a heavily shaded environment (Fig. 4), which probably facilitated the snake's daytime movement on the surface with minimal risk of dehydration. The snake apparently was captured while trying to escape because it was being ingested tail-first, contrary to Colón's (2009) observation of headfirst ingestion by Anolis cristatellus.

The specific identity of the blindsnake could not be determined due to the damaged condition of its body (Fig. 2B). The visible characteristics allowed us to place it in the $T$. lumbricalis species group (sensu Domínguez and Díaz 2011), and some characters coincide with the recently described $T$. leptolepis (see Domínguez et al. 2013), but we were unable to definitively assign the specimen to that species. 


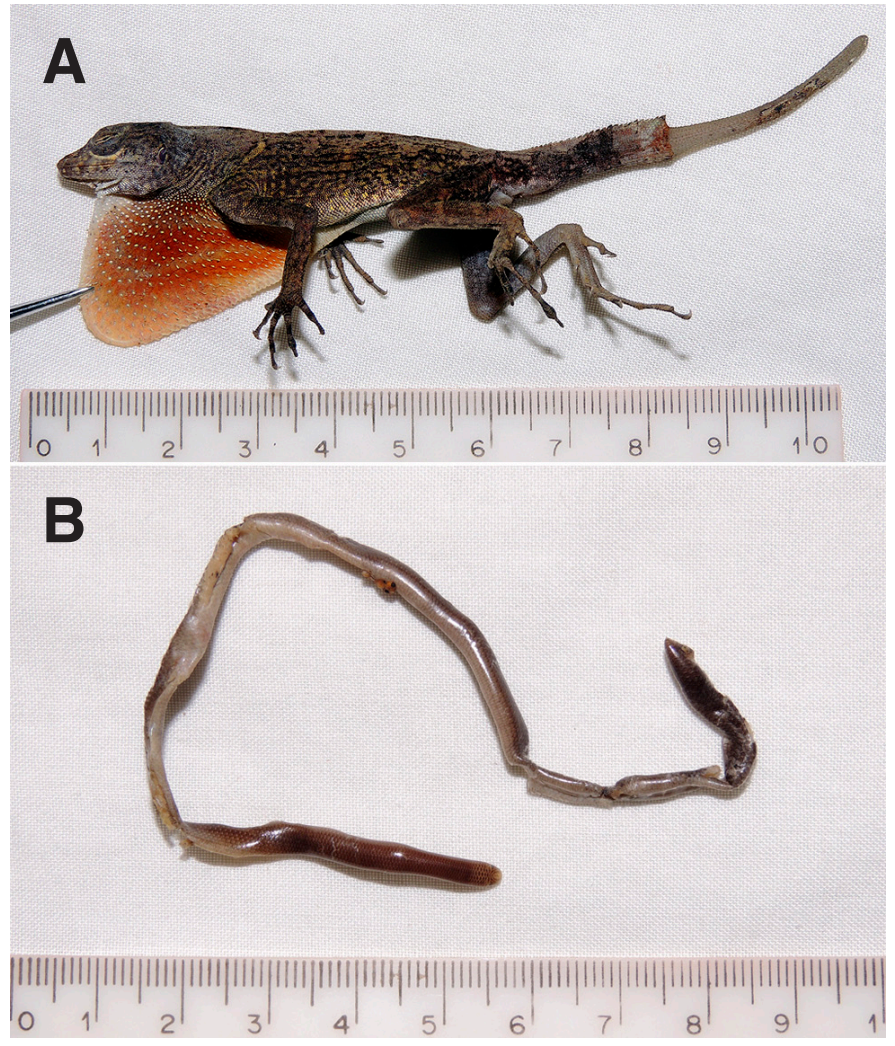

Fig. 2. Specimens of the anole predator (Anolis allogus; A) and the Blindsnake prey (Typhlops sp.; B) collected along the ascending path to El Yunque, Baracoa, Guantánamo Province.

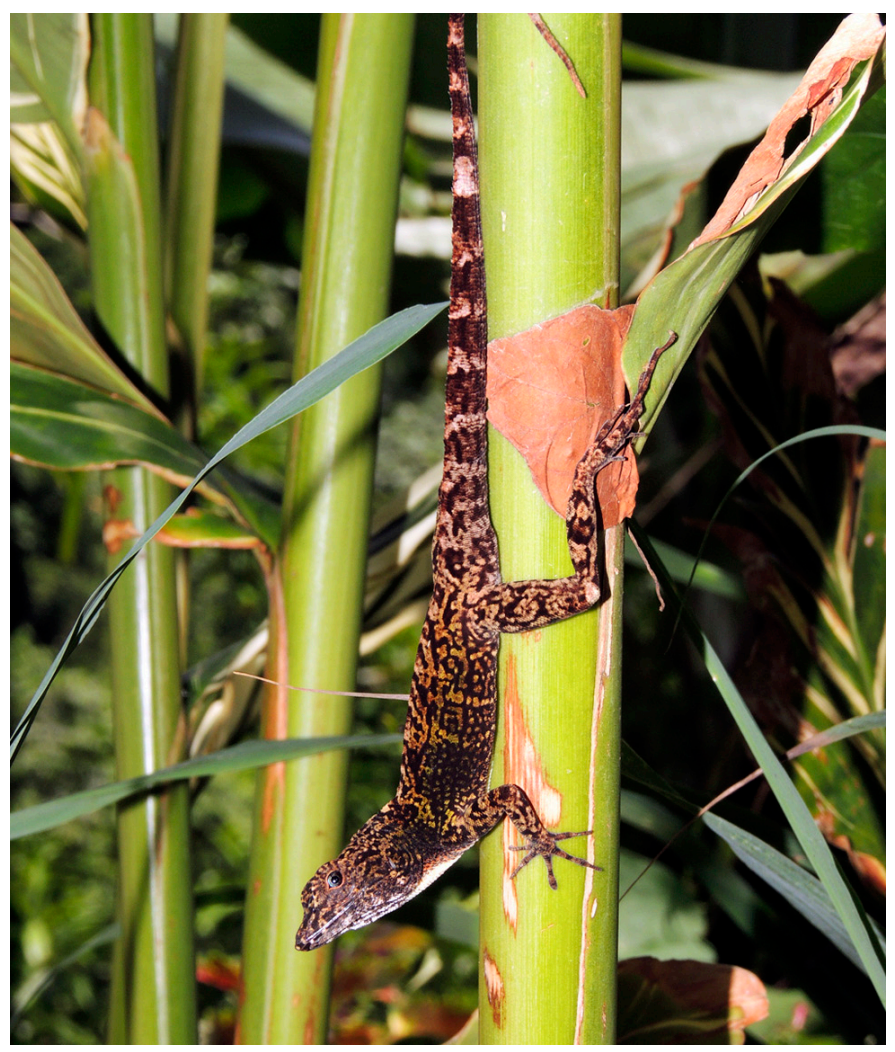

Fig. 3. Male Spanish Flag Anole (Anolis allogus) from El Yunque, Baracoa, Guantánamo Province.

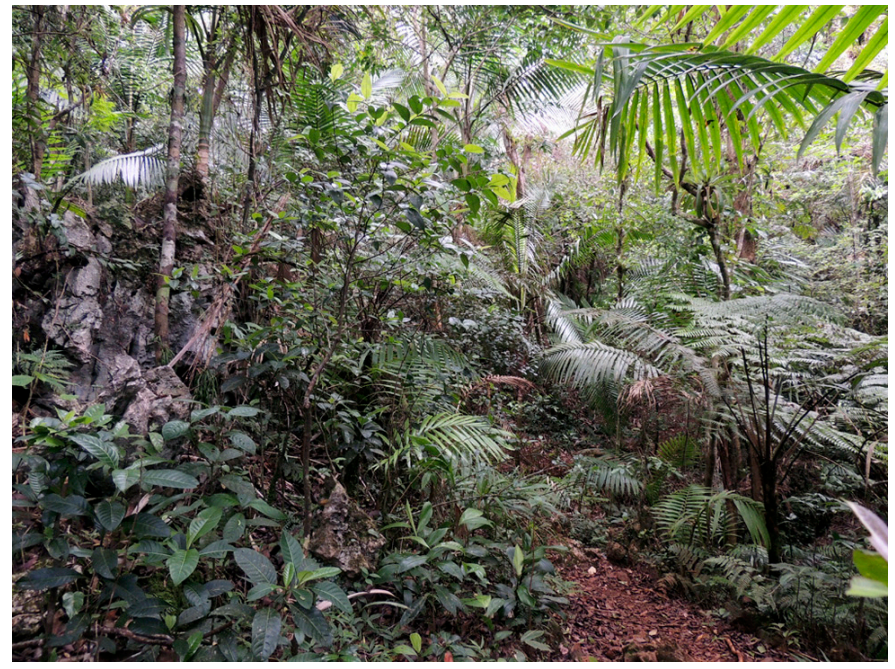

Fig. 4. Habitat where we observed the male Spanish Flag Anole (Anolis allogus) preying on a Blindsnake (Typhlops sp.) along the ascending path to El Yunque, Baracoa, Guantánamo Province.

\section{Acknowledgements}

We thank Javier Torres, Ruben Marrero, Robert Powell, and Manuel Iturriaga for providing literature references. Javier Torres also made useful comments on the manuscript.

\section{Literature Cited}

Brooks, G.R., Jr. 1982. An analysis of prey consumed by the anuran, Leptodactylus fallax, from Dominica, West Indies. Biotropica 14:301-309.

Colón Archilla, A.D. 2009. Turning the tables: Lizard eats snake. Reptiles \& Amphibians 16:28-29.

Díaz, L.M. and A. Cádiz. 2014. First record of the Brahminy Bindsnake, Indotyphlops braminus (Squamata: Typhlopidae) in Cuba. Reptiles \& Amphibians 21:140-141.

Domínguez, M. 2015. Resurrection and redescription of the Typhlops silus Legler, 1959 from Cuba (Scolecophidia, Typhlopidae). Journal of Herpetology 49:325-331.

Domínguez, M., A. Fong, and M. Iturriaga. 2013. A new blind snake (Typhlopidae) from Northeastern Cuba. Zootaxa 3681:136-146.

Domínguez, M. and R.E. Díaz. 2011. Taxonomy of the blind snakes associated with Typhlops lumbricalis Linnaeus, 1758 (Scolecophidia, Typhlopidae) from Bahama Islands and Cuba. Herpetologica 67:194-211.

Hedges, S.B., A.B. Marion, K.M. Lipp, J. Marin, and N. Vidal. 2014. A taxonomic framework for typhlopid snakes from the Caribbean and other regions (Reptilia, Squamata). Caribbean Herpetology 49:1-61.

Henderson, R.W. and R. Powell. 2009. Natural History of West Indian Amphibians and Reptiles. University Press of Florida, Gainesville.

Henderson, R.W. and R.A. Sajdak. 1996. Diets of West Indian racers (Colubridae: Alsophis): Composition and biogeographic implications, pp. 227-338. In: R. Powell and R.W. Henderson (eds.), Contributions to West Indian Herpetology: A Tribute to Albert Schwartz. Contributions to Herpetology. Volume 12, Society for the Study of Amphibians and Reptiles, Ithaca, New York.

Hernández-Prieto, E. 1987. Typhlops monensis (Mona Island Blind Snake). Predation. Herpetological Review 18:76.

Nagy, Z.T., A.B. Marion, F. Glaw, A. Miralles, J. Nopper, M. Vences, and S.B. Hedges. 2015. Molecular systematics and undescribed diversity of Madagascan scolecophidian snakes (Squamata: Serpentes). Zootaxa 4040:31-47.

Pyron, R.A. and V. Wallach. 2014. Systematics of the blindsnakes (Serpentes: Scolecophidia: Typhlopoidea) based on molecular and morphological evidence. Zootaxa 3829:1-81.

Rivero, J.A. 1998. Los Anfibios y Reptiles de Puerto Rico. Segunda edición revisada. 
The Amphibians and Reptiles of Puerto Rico. Second edition revised. University of Puerto Rico, San Juan.

Rodríguez Schettino, L., C.A. Mancina, and V. Rivalta González. 2013. Reptiles of Cuba: Checklist and geographic distributions. Smithsonian Herpetological Information Service 144:1-96.

Schwartz, A. and R.W. Henderson. 1991. Amphibians and Reptiles of the West Indies: Descriptions, Distributions, and Natural History. University of Florida Press, Gainesville.

Schwartz, A. and D.A. Rossman. 1976. A review of the Hispaniolan colubrid snake genus Ialtris. Studies on the Fauna of Curaçao and Other Caribbean Islands 50:76-102.

Socarrás, A.A., J. de la Cruz, G. Garcés G., and A. Ruiz. 1988. Saurofagia en Anolis (Sauria: Iguanidae). Miscelánea Zoológica 38:4.

Vitt, L.J. and J.P. Caldwell. 2009. Herpetology: An Introductory Biology of Amphibians and Reptiles. Third Edition. Academic Press, San Diego, California.

Wallach, V. 2009. Indotyphlops braminus (Daudin): A synopsis of morphology, taxonomy, nomenclature and distribution (Serpentes: Typhlopidae). Hamadryad 34:34-61. 